\title{
Two New Microbrotula (Teleostei: Ophidiiformes: Bythitidae) from the Southwestern Pacific Ocean, with a Revised Key to the Species
}

\author{
M. Eric Anderson \\ South African Institute of Aquatic Biodiversity, Private Bag 1015, \\ Grahamstown 6140, South Africa \\ E-mail:E.Anderson@ru.ac.za
}

(Received 17 August 2006; Accepted 28 November 2006)

\begin{abstract}
Two new species of livebearing brotula of the genus Microbrotula Gosline are described from the tropical southwestern Pacific. Microbrotula greenfieldi sp. nov., from Fiji, is distinguished from its congeners by lacking head pores, its retrograde pelvic fins, relatively high pectoral fin ray count, low vertebral count, short pectoral fin, and dorsal fin origin above the eighth vertebra. Microbrotula punicea sp. nov., from the Kermadec Islands, is distinguished from its congeners by the presence of four preoperculomandibular pores, its high vertebral and pectoral fin ray counts, advanced pelvic fins, long pectoral fin, and dorsal fin origin above the ninth vertebra.

Key Words: Teleostei, Ophidiiformes, Bythitidae, Microbrotula, new species, Kermadec Islands, Fiji, South Pacific Ocean, key.
\end{abstract}

\section{Introduction}

The livebearing brotula genus Microbrotula Gosline, 1953 was known in the literature from 11 specimens of two species collected in the tropical Pacific until Anderson (2005) reviewed the genus and described three new species. Two of these, $M$. polyactis Anderson, 2005 and $M$. queenslandica Anderson, 2005, are also tropical Pacific forms whereas the other, $M$. bentleyi Anderson, 2005, occurs in the western Indian Ocean. During that study other specimens of Microbrotula were made known to me but were unavailable for logistical reasons. Recently, however, these specimens were located and discovered to represent two more undescribed species, named herein. Both fit the re-diagnosis of Microbrotula given by Anderson (2005) and differ from their congeners in a few species-specific characters. Here I also provide a revised key to all the species of Microbrotula.

\section{Materials and Methods}

In 2002 David W. Greenfield, then of the University of Hawaii, conducted a twoyear survey of the marine fishes of Fiji. Collections at a total of 325 scuba poison stations were made by his team. West of the island of Vanua Levu at Pascoe Reefs 
in $35-45 \mathrm{ft}(10.6-13.7 \mathrm{~m})$ two specimens of a new Microbrotula species were collected. This species appeared close to the Indian Ocean $M$. bentleyi in its pectoral fin ray count, location of its dorsal fin origin, and number of lateral scale rows, but primarily differed in its slightly greater number of vertebrae, larger eye, wider interorbital space, and longer snout. In addition, Richard L. Pyle of the Bernice P. Bishop Museum, Honolulu, Hawaii, collected a specimen of the same species in a deep-reef area off Suva harbor, Fiji, where Dr Greenfield and associates had made collections of shallow-water reef fish. Dr Pyle's collections were made during mixed-gas, closed-circuit rebreather dives in depths of about 50-150 m (Pyle 2005).

In November, 2004, Andrew Stewart of the Museum of New Zealand and a party of scuba divers conducted a six-day survey of fishes and sessile invertebrates off western Raoul Island in the Kermadec Islands from the vessel Southern Salvor. Collections at nine poison stations were made in depths of $0-15.5 \mathrm{~m}$. Seven specimens of a new Microbrotula species were collected, four of which (at $45.6-57.6 \mathrm{~mm}$ SL) were larger than any previously reported specimen of the genus ( $M$. rubra Gosline, 1953 to $45.0 \mathrm{~mm} \mathrm{SL}$ ) (Gosline 1953; Anderson 2005). The species appeared close to M. rubra in its uniform pinkish orange color and pectoral fin ray counts but differed mainly in its fewer vertebrae and consequently fewer dorsal and anal rays, larger eye, narrower interorbital space, fewer lateral scale rows, more advanced pelvic fins, and presence of head pores.

All measurements are straight-line distances made with calipers or an ocular micrometer to the nearest $0.1 \mathrm{~mm}$. Counts of features of the axial skeleton were made from radiographs, and vertebral counts include the urostyle. The key to species proposed in this study requires high-quality radiographs. Ophidiiform terminology follows Cohen and Nielsen (1978) and Nielsen and Cohen (1999). Institutional abbreviations for depository of the specimens examined, including the type series of the new species, are: BPBM, Bernice P. Bishop Museum, Honolulu, USA; CAS, California Academy of Sciences, San Francisco, USA; and NMNZ, Museum of New Zealand Te Papa Tongarewa. Other abbreviations are: HL, head length; SL, standard length.

\section{Systematics}

Microbrotula greenfieldi sp. nov. (Fig. 1)

Material examined. Holotype: CAS 222542, male ( $34.3 \mathrm{~mm} \mathrm{SL}$ ), Fiji, Vanua Levu, Pascoe Reefs, 3rd reef W of Yadua Island, $16^{\circ} 50.188^{\prime} \mathrm{S}, 178^{\circ} 13.665^{\prime} \mathrm{E}$, scuba stn G02-135, 10.6-13.7 m, 09:30-10:30 hr., 4 April 2002, coll. D. W. Greenfield, K. Longenecker, and R. Langston. Paratypes: CAS 223980, male (30.6 mm SL), same collection as holotype; BPBM 39982, female ( $41.8 \mathrm{~mm} \mathrm{SL})$, Fiji, Viti Levu Island, outside Suva harbor, $18^{\circ} 09.550^{\prime} \mathrm{S}, 178^{\circ} 23.974^{\prime} \mathrm{E}$, scuba, 86.9-93.3 m, 3 February 2003, coll. R. L. Pyle and D. F. Pence.

Diagnosis. A species of Microbrotula as defined by Cohen and Wourms (1976) and Anderson (2005) with the following combination of characters: vertebrae $11+36-37=47-48$; pectoral fin rays 14; head pores absent; pectoral fin length $12.4-17.0 \% \mathrm{SL}$; distance from cleithral symphysis to pelvic fin insertion $10.1-10.4 \%$ 
SL; orbit diameter $15.8-18.3 \% \mathrm{HL}$; snout length $18.3-22.7 \% \mathrm{HL}$; dorsal fin origin above vertebra 8; male copulatory apparatus with 3 small papillae at base of main genital papilla.

Counts and proportions. Holotype first, followed in parentheses by range of paratypes: vertebrae $11+37=48(11+36=47)$; dorsal fin rays $70(68)$; anal fin rays 61 (58 60); caudal fin rays 6 (6); pectoral fin rays 14 (14); pelvic fin rays 1 (1); developed gill rakers 3 (3); vomerine teeth 15 (7-18); palatine teeth 4/5 (2-7/3-4). Following proportions as percent SL: head length 28.3 (27.6-28.7); head width 12.7 (11.5-12.6); head depth 15.9 (16.0-17.9); predorsal length 35.9 (36.4-36.6); preanal length 48.3 (49.0-49.8); prepelvic length 23.7 (24.6-26.6); body depth 13.7 (14.9-18.2); pectoral fin length 12.4 (14.1-17.0); pelvic fin length (broken in holotype) (18.2-20.8); distance from cleithral symphysis to pelvic fin insertion 10.3 (10.1-10.4). Following proportions as percent HL: head width 44.9 (40.0-45.7); head depth 56.2 (58.0-62.5); prepelvic length 83.8 (89.0-92.5); orbit diameter 16.5 (15.8-18.3); snout length 22.7 (18.3-20.7); fleshy interorbital width 21.7 (20.8-22.5); body depth 48.5 (54.0-63.3); upper jaw length 51.6 (49.2-54.4); pectoral base depth 19.6 (18.3-18.9); pectoral fin length 43.8 (50.9-59.2); pelvic fin length (damaged in holotype) (66.0-72.5); distance from cleithral symphysis to pelvic fin insertion 36.4 (36.3-36.7).

Description. Head moderately elongate, postorbital length slightly less than 3 times snout length; lateral profile of head gently sloping from nape to snout tip, no concavity. Head deeper than wide at occiput. Tip of snout slightly projecting beyond upper lip; 2 or 3 low, parallel, fleshy ridges on top of snout with scattered low, white sensory papillae between these ridges not formed into rows but extending to interorbital area. Top of head with ill-defined row of papillae in postorbital region; no papillae on nape or occiput. Two parallel rows of papillae on mandible reaching just to mouth rictus. Two ill-defined rows of minute papillae under eye, much reduced in largest specimen. Upper jaw extending well beyond eye, expanded posteriorly, sheathed in long, fleshy pocket extending along entire jaw; posterior jaw margin free at posteroventral corner, with slight triangular projection. Teeth on jaws viliform, in 4 or 5 bands anteriorly, 3 or 4 bands posteriorly, with $1+2$ (males) or no (female) caniniform teeth in upper jaws and $5+5$ (males) or $0+2$ (female) caniniform teeth in lower jaws. Caniniform vomerine teeth in 2 patches of $4+4$ (holotype), $2+2$ (CAS 223980), or 9+9 (BPBM 39982), interspersed with a few viliform teeth. Palatine teeth minute, in single series, only anteriormost teeth erupted, unerupted tooth buds observed posteriorly. No head pores. Eye small, rounded; translucent orbital spectacle covering eye.

Scales cycloid, imbricate, deciduous, not covered by thick skin; no scales on unpaired fins or jaws. Scales present on pectoral base but not on fin or in axil. Scales on head extending from nape to occiput just behind eyes and ventrally covering operculum and cheek but not suborbital region.

Gill opening extending ventrally to isthmus positioned slightly more than 1 eye diameter posterior to level of rear margin of upper jaw. Three developed, toothed gill rakers on upper limb of first arch, remaining 4 rakers as mere tooth pads. Pectoral fin on short peduncle about twice as high as long; rays reaching almost to anus. Pelvic fin tips of holotype broken off, appressed pelvic fins of paratype BPBM 39982 reaching middle of cloaca. Pelvic fin insertion directly below rear margin of operculum. Dorsal fin origin above posterior quarter of pectoral fin, above vertebra 8 . Anal fin origin at mid-body, under vertebra 14. Male copulatory 

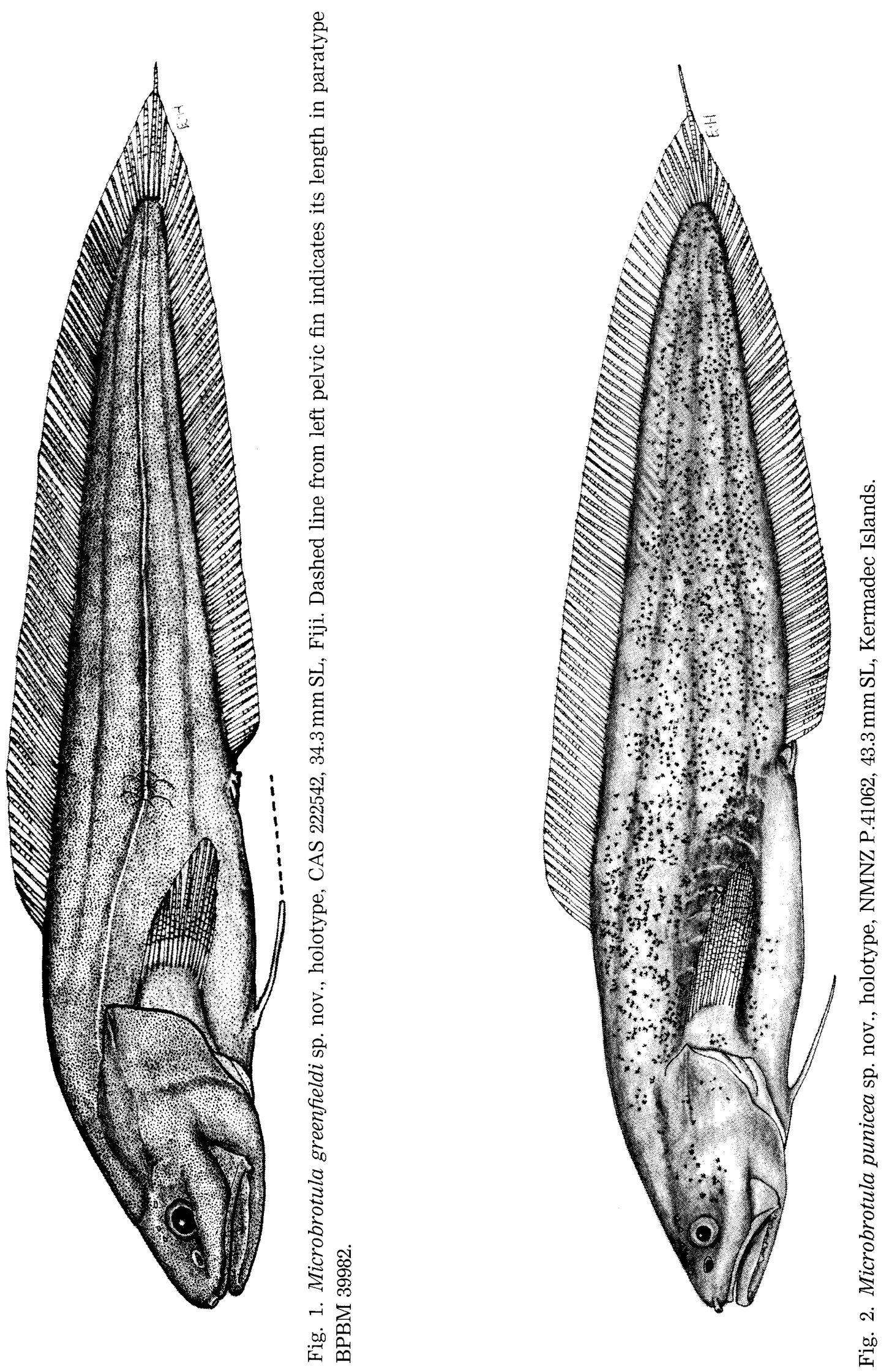
apparatus with low, ovoid, fleshy hood immediately anterior to anal fin origin. Anterior end of hood with simple, elongate genital papilla with 3 smaller papillae at its base. No lobes on main papilla.

Fresh coloration (from a photograph provided by D. W. Greenfield) uniformly lavender, head blackish purple, eye blue. Preserved specimens uniformly light brown.

Etymology. Named in honor of the collector, David W. Greenfield, for his numerous contributions to the systematics, conservation, behavior, and ecology of fishes.

Distribution and habitat. Known only from off Yadua Island and Suva harbor, Fiji, from outer reef areas at depths of about 11-93 $\mathrm{m}$.

Remarks. This species seems close to the western Indian Ocean Microbrotula bentleyi in its similar meristics of the axial skeleton, pectoral fin, and scale rows, and its dark coloration. Microbrotula bentleyi is bluish gray or brown (Anderson 2005) whereas $M$. greenfieldi is generally lavender. The new species further differs in its larger eye (orbit 15.8-18.3\% HL in $M$. greenfieldi vs $10.9-13.9 \%$ HL in $M$. bentleyi), broader interorbital space $(20.8-22.5 \% \mathrm{HL}$ in $M$. greenfieldi vs $16.8-19.8 \% \mathrm{HL}$ in $M$. bentleyi), and longer snout (18.3-22.7\% $\mathrm{HL}$ in $M$. greenfieldi vs $16.7-19.8 \% \mathrm{HL}$ in $M$. bentleyi). Vertebral differences between the two species may overlap when more specimens are found; at present $M$. greenfieldi $(\mathrm{N}=3)$ has $47-48$ total vertebrae vs $44-46$ for $M$. bentleyi $(\mathrm{N}=6)$.

\section{Microbrotula punicea sp. nov.}

(Figs 2, 3)

Material examined. Holotype: NMNZ P.41062, male (43.3 mm SL), Kermadec Islands, Raoul Island, Denham Bay, $2^{\circ} 16.3^{\prime} \mathrm{S}, 177^{\circ} 57.0^{\prime} \mathrm{W}, 8.5-11.5 \mathrm{~m}$, stn KRI 004, 6 November 2004, coll. A. Stewart and party, rotenone and scuba. Paratypes: NMNZ P.42334, 2 males (41.1, 45.6 mm SL), same collection as holotype; NMNZ P.41036, 2 females (52.2, $57.6 \mathrm{~mm} \mathrm{SL}), 1$ male $(38.5 \mathrm{~mm} \mathrm{SL})$, Kermadec Islands, Raoul Island, Meyer Islet, $29^{\circ} 14.7^{\prime} \mathrm{S}, 177^{\circ} 53.1^{\prime} \mathrm{W}, 8.5-11.5 \mathrm{~m}$, stn KRI 005, 7 November 2004, coll. A. Stewart and party; NMNZ P.41086, 1 female $(52.4 \mathrm{~mm} \mathrm{SL})$, Kermadec Islands, Raoul Island, Denham Bay, $29^{\circ} 17.1^{\prime} \mathrm{S}, 177^{\circ} 57.3^{\prime} \mathrm{W}, 14.5-15.5 \mathrm{~m}$, stn KRI 011, coll. A. Stewart and party.

Diagnosis. A species of Microbrotula as defined by Cohen and Wourms (1976) and Anderson (2005) with the following combination of characters: vertebrae $11-12+40-42=51-53$; pectoral fin rays 14; 1 preopercular and 3 mandibular pores; prepelvic length $18.7-22.1 \%$ SL; distance from cleithral symphysis to pelvic fin insertion $4.4-5.4 \%$ SL; pectoral fin length $60.0-67.0 \% \mathrm{HL}$; fleshy interorbital width 16.5-20.3\% HL; orbit diameter $13.5-17.1 \% \mathrm{HL}$; dorsal fin origin above vertebra 9 .

Counts and proportions. Holotype first, followed in parentheses by range in paratypes: vertebrae $11+40=51(11-12+40-42=51-53)$; dorsal fin rays 78 (79-81); anal fin rays 64 (65-71); caudal fin rays 6 (6); pectoral fin rays 14 (14); pelvic fin rays 1 (1); developed gill rakers 3 (3); vomerine teeth 8 (4-11); palatine teeth $5 / 5$ (4-7/5-7). Following proportions as percent SL: head length 25.2 (24.8-26.8); head width 9.0 (9.5-11.1); head depth 13.9 (13.9-15.6); predorsal length 36.5 (36.3-38.9); preanal length 49.4 (52.3-56.9); prepelvic length 21.4 (18.7-22.1); body depth 14.6 (13.7-16.0); 


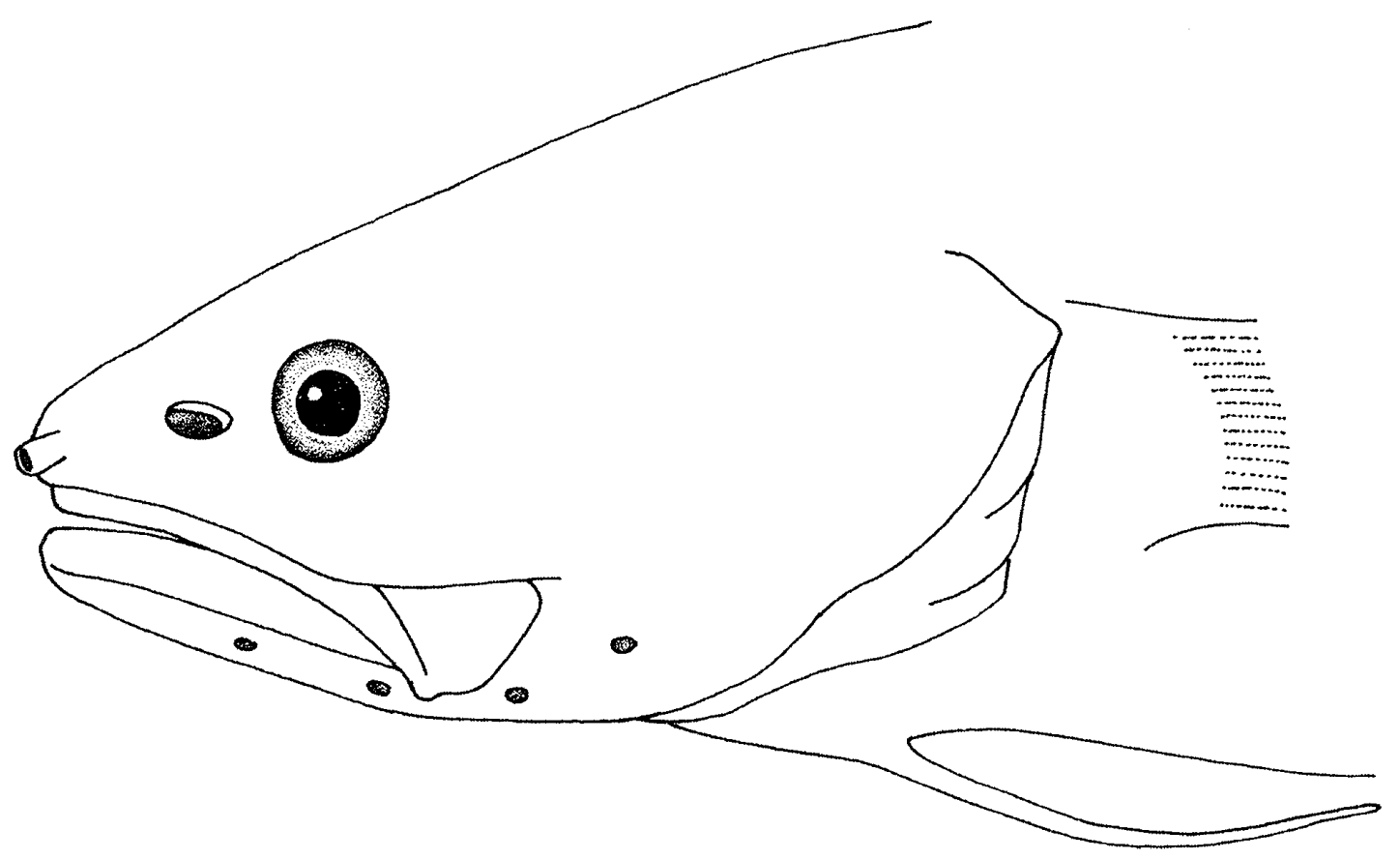

Fig. 3. Head of holotype of Microbrotula punicea sp. nov., NMNZ P.41062, showing location of preoperculomandibular pores.

pectoral fin length 15.9 (15.8-17.9); pelvic fin length 13.2 (13.5-16.4); distance from cleithral symphysis to pelvic fin insertion 5.2 (4.4-5.4). Following proportions as percent HL: head width 35.8 (37.9-41.7); head depth 55.1 (53.1-58.3); prepelvic length 84.9 (75.4-82.5); orbit diameter 13.5 (13.5-17.1); snout length 18.8 (15.4-19.1); fleshy interorbital width 16.5 (17.1-20.3); body depth 57.8 (55.4-59.7); upper jaw length 50.5 (44.6-49.3); pectoral base depth 21.6 (17.9-19.4); pectoral fin length 63.3 (60.0-67.0); pelvic fin length $52.3(54.2-61.2)$; distance from cleithral symphysis to pelvic fin insertion 21.4 (16.8-21.0).

Description. Head moderately elongate, postorbital length about 3 times snout length; snout above eye slightly concave, less pronounced in largest specimens. Head deeper than wide. Snout tip evenly rounded in largest fish, squared off in smallest, not overhanging upper lip. Top of snout with 3 parallel fleshy ridges bearing longitudinal rows of low sensory papillae; ridges better defined and papillae more numerous in larger specimens than smallest. Top of head with parallel rows of papillae in postorbital area and one row across occiput. Two parallel rows of papillae on mandible reaching to lower edge of preopercle in largest specimens. Two parallel rows of papillae under eye. Upper jaw extending well beyond eye, expanded posteriorly, sheathed in long, fleshy pocket not extending entire length of jaw; posterior jaw margin free; posteroventral corner with slight triangular projection. Teeth on jaws viliform, in 3 bands, with a few caniniform teeth anteriorly and laterally in upper jaw and only laterally in lower jaw. Caniniform vomerine teeth in 2 patches of $2+3$ (holotype) or $2-3+2-4=4-7$ (paratypes), interspersed with a few viliform teeth. Palatine teeth recurved, in single row. Three mandibular pores arising from ventral margin of lower jaw and 1 preopercular pore arising from lower end of cheek (Fig. 3). Eye small, rounded; translucent orbital spectacle cover- 
ing eye.

Scales cycloid, imbricate, covered by moderately thick skin, thus making lateral series counts impossible; no scales on unpaired fins or jaws. Scales present on pectoral base but not on fin or in axil. Scales on head extending from nape to interorbital area and ventrally covering operculum and cheek to posterior part of suborbital area.

Gill opening extending ventrally to isthmus positioned about 1 eye diameter posterior to level of rear margin of upper jaw. Three developed, toothed gill rakers on upper limb of first arch, remaining 5 or 6 rakers as mere toothed pads. Pectoral fin on short peduncle about 3 times higher than long; rays reaching almost to anus, but several specimens with damaged fins. Undamaged pelvic fin reaching just beyond midlength of pectoral fin. Pelvic fin insertion directly below middle of operculum. Dorsal fin origin above posterior quarter of pectoral fin; above vertebra 9 . Anal fin origin at mid-body, under vertebra 14. Male copulatory apparatus with low, ovoid, fleshy hood immediately anterior to anal fin origin. Anterior end of hood with simple, elongate genital papilla with pair of smaller papillae at its base. No lobes on main papilla.

Fresh coloration uniformly pinkish orange, dorsal and anal fins dark brown, eye blue. Preserved specimens whitish with small, scattered melanophores.

Etymology. From the Latin puniceus (pink or reddish) in reference to its live coloration. The gender of Microbrotula is feminine (Eschmeyer 1990).

Distribution and habitat. Known only from Raoul Island, Kermadec Islands, in areas with fine soft sediment in reef crevices and holes or under boulders in 8.5-15.5 $\mathrm{m}$ deep.

Remarks. Of the seven known species of Microbrotula, only $M$. punicea and the more northerly $M$. randalli Cohen and Wourms, 1976 have cephalic lateralis pores. The pores in $M$. randalli are arranged in a quincunx pattern on top of the head (Cohen and Wourms 1976) unlike the four preoperculomandibular pores of $M$. punicea (Fig. 3).

\section{Key to Species of Microbrotula}

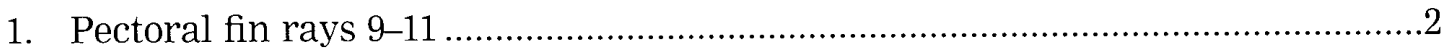

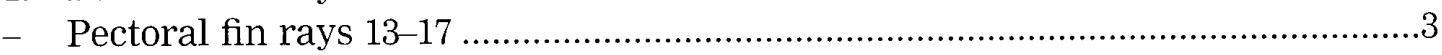

2. Five head pores in quincunx pattern in interorbital area; predorsal length $40.0-47.6 \%$ SL (dorsal fin origin above vertebrae 10-11); distance from symphysis of cleithra to pelvic fin insertion $10.7-14.8 \%$ HL; lateral scale series 63-66; total vertebrae $52-56$. M. randalli

- No head pores; predorsal length $34.6 \%$ SL (dorsal fin origin above vertebra 7 ); .. distance from symphysis of cleithra to pelvic fin insertion $26.2-28.2 \% \mathrm{HL}$; lateral scale series $56-57$; total vertebrae $48-49$

3. Pectoral fin rays 13-14; caudal fin rays 4-6; lateral scale series $54-c a .60 \ldots \ldots \ldots . . . .4$

- Pectoral fin rays 16-17; caudal fin rays 7-8; lateral scale series 47-50

M. polyactis

4. Vertebrae 11-12+36-42; prepelvic length 18.7-24.7\% SL ...................................

- Vertebrae 11+33-35; prepelvic length 24.3-26.7\% SL ............................. bentleyi

5. Orbit diameter $13.5-18.3 \% \mathrm{HL}$; fleshy interorbital width $16.5-22.5 \%$ HL .............6 
- Orbit diameter 6.5-9.1\% HL; fleshy interorbital width 23.8-27.8\% HL ...M. rubra

6. Vertebrae 11-12+40-42; dorsal fin rays 78-81; dorsal fin origin above vertebra 9; pelvic fin insertion on vertical through middle of operculum; distance from symphysis of cleithra to pelvic fin insertion $16.8-21.4 \%$ HL; prepelvic length $18.7-22.1 \%$ SL. $M$. punicea sp. nov.

- Vertebrae 11+36-37; dorsal fin rays 68-70; dorsal fin origin above vertebra 8; pelvic fin insertion on vertical through rear margin of operculum; distance from symphysis of cleithra to pelvic fin insertion $36.3-36.7 \% \mathrm{HL}$; prepelvic length $23.7-26.6 \%$ SL M. greenfieldi sp. nov.

\section{Acknowledgements}

Andrew Stewart, NMNZ, collected the Kermadec specimens, supplied photographs of a fresh one, and helped with curatorial needs. The Kermadecs expedition was sponsored in part by the "Biosystematics of New Zealand Exclusive Economic Zone Fishes Programme" funded by the New Zealand Foundation for Research Science and Technology, contract MNZX0203, Clive D. Roberts, program leader. Collecting in the Kermadec Marine Reserve was undertaken by permit from the Department of Conservation (Auckland). David W. Greenfield, Moss Landing Marine Laboratories, USA, collected and supplied a photograph of the Fiji specimens. That project, "A Survey of the Marine Fishes of Fiji", was sponsored by U.S. National Science Foundation grant INT97-29666 and Sea Grant Project R/FM-6PD, D. W. Greenfield, principal investigator, and DEB-0102745, D. W. Greenfield and J. E. Randall, co-investigators. Jørgen G. Nielsen, Zoologisk Museum, Copenhagen, and Werner Schwarzhans, Hamburg, Germany, aided with the curation of R. L. Pyle's Fiji specimen. David Catania, California Academy of Sciences, also provided valuable curatorial assistance. Elaine Heemstra, South African Institute of Aquatic Biodiversity, rendered the fine illustrations.

\section{References}

Anderson, M. E. 2005. Three new species of Microbrotula (Teleostei: Ophidiiformes: Bythitidae) from the Indo-West Pacific. Zootaxa 1006: 33-42.

Cohen, D. M. and Nielsen, J. G. 1978. Guide to the identification of genera of the fish order Ophidiiformes, with a tentative classification of the order. NOAA Technical Report, NMFS Circular 417: 1-72.

Cohen D. M. and Wourms, J. P. 1976. Microbrotula randalli, a new viviparous ophidioid fish from Samoa and New Hebrides, whose embryos bear trophotaenia. Proceedings of the Biological Society of Washington 89: 81-98.

Eschmeyer, W. N. 1990. Catalog of the Genera of Recent Fishes. California Academy of Sciences, San Francisco, 697 pp.

Gosline, W. A. 1953. Hawaiian shallow-water fishes of the family Brotulidae, with the description of a new genus and notes on brotulid anatomy. Copeia 1953: 215-225.

Nielsen, J. G. and Cohen, D. M. 1999. Family Bythitidae. Pp. 94-135. In: Nielsen, J. G., Cohen, D. M., Markle, D. F. and Robins, C. R. (Eds) FAO Species Catalogue, Vol. 18. Ophidiiform Fishes of the World (Order Ophidiiformes). FAO, Rome.

Pyle, R. L. 2005. Recent discoveries of new fishes inhabiting deep Pacific coral reefs, with biogeographic implications. P. 98. In: Abstracts, Seventh Indo-Pacific Fish Conference, Taipei. 